\title{
LIQUIDITY AS A MEASURE OF EFFICIENCY OF FRUIT AND VEGETABLE PRODUCER GROUPS AND ORGANIZATIONS
}

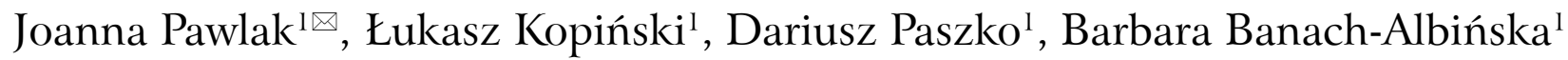 \\ ${ }^{1}$ University of Life Sciences in Lublin, Poland
}

\begin{abstract}
This study attempts to assess the financial liquidity of fruit and vegetable producer groups and organizations. Based on static liquidity ratios, the analysis was used for a preliminary assessment of the financial condition of the abovementioned economic operators in the context of forecasting their further market activity. Financial statements from 2012 2015 served as research material. The survey extended to 78 groups and organizations of fruit and vegetable producers. As shown by the results, most of the operators surveyed failed to meet all the criteria of financial liquidity management. The average and median values of current, quick and cash ratios suggest that the operators face quite a high liquidity risk. This was confirmed by the results of detailed studies which showed that the liquidity ratios reported by ca. $60 \%$ of the operators were below the recommended optimum. Therefore, in the reporting period considered, such operators could be unable to meet their liabilities as they fall due. This may pose a severe threat to their continued existence and further development.
\end{abstract}

Keywords: financial liquidity, producer groups, producer organizations, horticultural

\section{INTRODUCTION}

Polish horticultural farms are quite a diverse group of operators, from small to large-scale producers, some of which are specialized and rely on state-of-the-art technologies. Whatever their size, production type or technological sophistication may be, each of them has to adapt to business requirements (Boguta, 2008). In the current context, market expectations specified by
Zmarlicki et al. (2013) can be met by producer groups and organizations. A collaborative approach provides many benefits for building a competitive advantage for farms (Camanzi et al., 2009; Nowak and Gąsior, 2017; Sobczak et al., 2013) and indirectly contributes to the development of the entire horticultural sector.

Industry information indicates that many producer groups and organizations are managing well, attract more and more members, hire more staff and succeed internationally. On the other hand, there is a growing number of business failures which become a worrying trend caused by multiple factors: insolvency of contractors, competition, limitation of financial support, lack of member loyalty, indebtedness and frequent inability to manage financial liquidity (www.sadyogrody.pl). The lack of liquidity (which may also be referred to as payment capacity) is a common reason for the demise of companies around the world (Florek and Czerwińska-Kayzer, 2012), including in Poland (Boratyńska, 2014; Rogowski, 2015). Therefore, maintaining an adequate level of liquidity should be one of the company's major goals, often more important than revenues (Kwiecień, 2015). In the short term, liquidity - rather than profitability - is crucial for an economic operator's ability to survive in the market (Cicirko, 2010). It should be noted, however, that liquidity is not the main goal for businesses, as it is also necessary to consider the effects of excessive liquidity or short-term loss of liquidity (Bieniasz and Gołaś, 2008). Excessive levels of liquidity (resulting from investing large amounts of own capital or allocating a large part of own resources to finance

$\bowtie$ PhD Eng Joanna Pawlak, Department of Managment and Marketing, The University of Life Sciences in Lublin, 37 Dobrzańskiego St., 20-262 Lublin, Poland, e-mail: joanna.pawlak@up.lublin.pl, https://orcid.org/0000-0002-1670-5043 
current operations), hinder the growth of profits due to ineffective use of borrowed capital and have an adverse effect on profitability (Mańko et al., 2008). On the other hand, reduced liquidity may lead to the loss of longterm solvency and to the bankruptcy of the company (Bieniasz and Gołaś, 2008). Therefore, the purpose of this study was to assess the liquidity of fruit and vegetable producer groups and organizations. The analysis was used for a preliminary assessment of their financial condition in the context of forecasting their further functioning and development ${ }^{1}$.

\section{METHODOLOGY}

Liquidity was assessed based on source data from financial statements of formal producer groups and organizations. They operate within the framework of a countrywide organization of the fruit and vegetable market. These operators were selected for analyses because the size of the above groups and organizations has been observed to change over recent years in Poland, and because this issue has not yet been subject to extensive research. The research results available in the literature usually address the sociological or production and technological aspects of the operators' activities, leaving aside the crucial issues related to the assessment of the financial standing in the context of forecasting their continued market activities.

The study covered four financial years, 2012-2015. The operators were selected purposefully, based on data availability, to reflect the variety ${ }^{2}$ of statuses (preapproved producer group or producer organization status) and legal forms. Financial statements from a total of 78 enterprises were reviewed, representing on average about $25 \%$ of all horticultural groups and producer organizations registered in Poland in 2012-2015. In the population surveyed, $77.9 \%$ were private limited companies; the share of approved producer organizations in successive years was $28.6 \%, 37.7 \%, 45.5 \%$, and $70.1 \%$,

\footnotetext{
${ }^{1}$ For the producer groups, the development also means they will transform into approved producer organizations upon meeting a number of conditions.

${ }^{2}$ In Poland, the number of horticultural producer groups and organizations was 316 (in 2012), 321 (in 2013), 311 (in 2014), and 305 (in 2015). The ownership structure was dominated by limited liability companies (with an average share of 70-80\%) and pre-approved producer groups (with an average share of 36$75 \%$ in the total population).
}

respectively. This means that each year the status of an approved producer organization was granted to a group of 6 to 15 pre-approved producer groups ${ }^{3}$. The analysis relied on the abovementioned differentiating characteristics because the approval status reflects the entity's level of development, both in financial and organizational terms. At a later stage of development, the status of an approved producer organization may affect the operators' ability to maintain adequate levels of liquidity. In turn, the legal and organizational form is closely related to management methods. Multistage management (as practiced by cooperatives, for instance) is much more difficult than managing a private limited company, and may be reflected in a weaker financial performance (Chlebicka, 2011).

The problem is illustrated by the example of mean and median values of current, quick and cash ratios. The analyses relied on geometric mean values which are less affected by extreme values than the arithmetic mean. This is a way to reduce the influence of individual extreme values on the mean level of the variable (Woźniak, 2002; Makać and Urbanek-Krzysztofiak, 2004). The current, quick and cash ratios calculated for producer groups and organizations were benchmarked against the defined and generally accepted standard values. According to Sierpińska and Wędzki (2005), standard values allow to assess an individual's position against the background of generally accepted economic principles, and generally do not lead to false conclusions or other failures. The research also presents the values of selected assets and liabilities and other economic and financial ratios of the operators covered by this audit.

\section{DEGREE OF ORGANIZATION OF FRUIT AND VEGETABLE PRODUCERS}

The disadvantageous size structure of farms, frequent reports of low productivity, high production costs and a low degree of horizontal integration affect the development of Polish horticulture and its competitiveness in the EU and worldwide (Strategia..., 2016).

\footnotetext{
${ }^{3}$ However, according to the list of groups and organizations of Polish fruit and vegetable producers (as at June 30, 2017), the group of approved entities included 3 approved organizations and 1 pre-approved group in winding up.

${ }^{4}$ In terms of the number of groups and producer organizations, the market seems to be well developed. However, the
} 
Pawlak, J., Kopiński, Ł., Paszko, D., Banach-Albińska, B. (2018). Liquidity as a measure of efficiency of fruit and vegetable producer groups and organizations. J. Agribus. Rural Dev., 2(48), 205-212. http://dx.doi.org/10.17306/J.JARD.2018.00402

Table 1. Degree of organization of fruit and vegetable producers in groups and organizations by voivodeships (as of June 3 , 2017)

\begin{tabular}{|c|c|c|c|c|c|c|c|}
\hline \multirow{2}{*}{ Voivodeship } & \multicolumn{2}{|c|}{ Total } & \multicolumn{2}{|c|}{ Level of approval } & \multicolumn{3}{|c|}{ Approved legal form } \\
\hline & number & $\%$ & $\begin{array}{c}\text { producer } \\
\text { organization }\end{array}$ & $\begin{array}{l}\text { producer } \\
\text { group }\end{array}$ & company & cooperatives & association \\
\hline Dolnośląskie & 10 & 3.55 & 7 & 3 & 10 & & \\
\hline Kujawsko-Pomorskie & 39 & 13.83 & 38 & 1 & 30 & 2 & 6 \\
\hline Lubelskie & 29 & 10.28 & 27 & 2 & 20 & 9 & \\
\hline Lubuskie & 5 & 1.77 & 5 & - & 5 & & 1 \\
\hline Łódzkie & 17 & 6.03 & 17 & & 14 & 2 & 1 \\
\hline Małopolskie & 11 & 3.90 & 11 & & 6 & 4 & 1 \\
\hline Mazowieckie & 85 & 30.14 & 82 & 3 & 79 & 5 & 1 \\
\hline Opolskie & 5 & 1.77 & 4 & 1 & 5 & & \\
\hline Podkarpackie & 6 & 2.13 & 6 & & 4 & 2 & \\
\hline Podlaskie & 1 & 0.35 & 1 & & 1 & & \\
\hline Pomorskie & 7 & 2.48 & 7 & & 6 & & 1 \\
\hline Śląskie & 4 & 1.42 & 3 & 1 & 4 & & \\
\hline Świętokrzyskie & 14 & 4.96 & 13 & 1 & 11 & 3 & \\
\hline Warmińsko-Mazurskie & 2 & 0.71 & 2 & & 2 & & \\
\hline Wielkopolskie & 46 & 16.31 & 46 & & 38 & 4 & 4 \\
\hline Zachodniopomorskie & 1 & 0.35 & & 1 & & & 1 \\
\hline Total & 282 & 100 & 269 & 13 & 235 & 31 & 16 \\
\hline
\end{tabular}

Source: own elaboration based on ARiMR data.

Therefore, the establishment of the producers' own organizations is the right move towards competitiveness. The "producer group/organization" means operators whose purpose is to market the members' products. Established on the initiative of individual producers, the groups/organizations are an extension of their farming activities (Czernyszewicz and Pawlak, 2012). Currently, there are two systems in Poland for the creation of, and financial support for, groups and organizations. The first one is intended for agricultural producer groups operating pursuant to the Act of September 15,

degree of market organization, measured by the value of fruits and vegetables marketed, does not exceed $20 \%$. The National Strategy for Sustainable Operational Programs of the Fruit and Vegetable Producers Organization in Poland for 2010-2016 includes a SWOT analysis of the fruit and vegetable market.
2000 concerning agricultural producer groups and their associations and amending other acts. The second one addresses groups and organizations of fruit and vegetable producers operating pursuant to Union and national legislation within the framework of the common organization of fruit and vegetable markets (Filipiak, 2013). According to the records of the Agency for Restructuring and Modernization of Agriculture (ARiMR), the degree of organization of fruit and vegetable producers in producer groups and organizations is quite low compared to agricultural producers. As of the end of 1H 2017, there were 282 fruit and vegetable producers and organizations in Poland, one association of fruit producer organizations (as of June 30, 2017), 1264 agricultural interest groups and 2 associations of agricultural producer groups (as of April 30, 2017). Table 1 presents the degree of organization of fruit and 
Pawlak, J., Kopiński, Ł., Paszko, D., Banach-Albińska, B. (2018). Liquidity as a measure of efficiency of fruit and vegetable producer groups and organizations. J. Agribus. Rural Dev., 2(48), 205-212. http://dx.doi.org/10.17306/JJARD.2018.00402

vegetable producers in producer groups and organizations in Poland by voivodeships and legal forms. The number of fruit and vegetable producer groups and organizations varied from one voivodeship to another. At the end of June 2017, most groups and organizations of fruit and vegetable producers were located in Mazowieckie (85), Wielkopolskie (46) and KujawskoPomorskie (39) voivodeships, representing a share of $30.14 \%, 16.31 \%$ and $13.83 \%$ at national level, respectively. The smallest numbers of producer groups and organizations were registered in the Zachodniopomorskie (1), Podlaskie (1), Warmińsko-Mazurskie (2), Śląskie (4) and Lubuskie (5) voivodeships. The 269 producer organizations were most prevalent. Only 13 operators were members of "pre-approved" groups or producer organizations pending approval. The legal form most commonly opted for by the producers was a limited liability company, adopted by 235 operators, representing $83.33 \%$ of the total pool of fruit and vegetable producer groups and organizations.

\section{LIQUIDITY ASSESSMENT}

In a context of market economy and fierce competition, liquidity is vital. It depends primarily on the operator's stage of development, market position, management skills and industry (Wasilewski, 2005), the amount and structure of liabilities and the amount and structure of assets which may be used to repay the liabilities (Mańko et al., 2008). As shown in Table 2, the groups and organizations of fruit and vegetable producers surveyed reported considerably different financial statement figures and liquidity ratios in the study period. This is evidenced by various factors, including the large differences in minimum and maximum values and in standard deviation. The balance-sheet total ranged from PLN 41 thousand to PLN 238.5 million, with an average level of PLN 15.8 million. Fixed assets were the dominant asset type. On average, current assets accounted only for $19.53 \%$ (ca. PLN 3 million) while half of the operators surveyed reported an even lower ratio (18.91\%).

Table 2. Selected descriptive statistics and ratios for groups and producer organizations under review in 2012-2015

\begin{tabular}{|c|c|c|c|c|c|c|}
\hline Specification & Min & $\operatorname{Max}$ & $\begin{array}{l}\text { Geometric } \\
\text { mean }\end{array}$ & Median & $\begin{array}{l}\text { Quartile } \\
\text { deviation }\end{array}$ & $\begin{array}{l}\text { Standard } \\
\text { deviation }\end{array}$ \\
\hline $\begin{array}{l}\text { Total assets/equity and liabili- } \\
\text { ties (PLN thousand) }\end{array}$ & 41 & 238,451 & 15,795 & 22,074 & 20,224 & 43,944 \\
\hline Current assets (PLN thousand) & 41 & 59,872 & 3,084 & 3,643 & 4,053 & 8,974 \\
\hline Liabilities (PLN thousand) & 0 & 238,856 & 11,342 & 19,315 & 17,276 & 42,966 \\
\hline $\begin{array}{l}\text { Short-term liabilities } \\
\text { (PLN thousand) }\end{array}$ & 0 & 81,471 & 3,013 & 4,345 & 4,671 & 12,050 \\
\hline $\begin{array}{l}\text { Share of current assets in } \\
\text { balance-sheet total (\%) }\end{array}$ & 0 & 100 & 19.53 & 18.91 & 10.17 & 25.91 \\
\hline $\begin{array}{l}\text { Share of liabilities in balance- } \\
\text { sheet total (\%) }\end{array}$ & 0 & 130.29 & 71.80 & 91.06 & 12.50 & 26.58 \\
\hline $\begin{array}{l}\text { Share of short-term liabilities } \\
\text { in total liabilities }(\%)\end{array}$ & 0 & 100 & 25,61 & 26.87 & 17.73 & 28.01 \\
\hline $\begin{array}{l}\text { Share of short-term liabilities } \\
\text { in balance-sheet total }(\%)\end{array}$ & 0 & 95.58 & 18.59 & 20.40 & 11.64 & 18.66 \\
\hline Current ratio (CR) & 0.01 & 19.53 & 1.04 & 1.06 & 0.43 & 4.19 \\
\hline Quick ratio (QR) & 0.01 & 17.99 & 0.69 & 0.72 & 0.40 & 3.78 \\
\hline Cash ratio & 0.005 & 12.89 & 0.06 & 0.08 & 0.13 & 2.64 \\
\hline
\end{tabular}

Source: own elaboration. 
According to Gabrusewicz (2005), current assets are of considerable importance for liquidity. The level of current assets reported by the operators deviated by slightly over PLN 4 million from the mean, and by $10.17 \%$ in relative terms (in the narrowed area of volatility). On average, the liabilities represented $71.80 \%$ (PLN 11.3 million) of the balance-sheet total, varying from 0 to PLN 238.9 million, and from $0 \%$ to as much as $130 \%$ in relative terms (a 130\% share of liabilities in the balance-sheet total was reported by one of the operators surveyed, and was due to a negative equity value in one of the years covered by the study period). This means the selected operators strongly rely on borrowed capital and a face high risk of inability to repay their debts. The results confirm that $50 \%$ of the producer groups and organizations surveyed had a payout ratio of $91.06 \%$ or more. Thus, as regards quite a large proportion of the operators surveyed, the overall debt ratio significantly deviated from the accepted standard, which, according to Gabrusewicz (2005), should be between 57\% and $67 \%$ to ensure financial stability. From the point of view of stability and continued smooth business operations, a worrying sign is that the maximum share of short-term liabilities in total liabilities reached $100 \%$. The average value of short-term liabilities in the study period amounted to PLN 3 million, with a $18.59 \%$ share in the balance-sheet total. However, it ranged from 0 to PLN 81.5 million (from 0 to almost $96 \%$ in relative terms). The latter value suggests that the operators surveyed find themselves in a highly disadvantageous financial situation and could face severe problems in maintaining adequate liquidity levels in the near future. This is confirmed by the average values of financial liquidity ratios throughout the study period. The average values of current, quick and cash ratios were 1.04, 0.69 and 0.06 , respectively, which is outside the recommended optimum range (Table 2). In addition, in the study period, for half of the operators surveyed, the levels of the current, quick and cash ratios were no higher than $1,06,0.72$ and 0.08 , respectively.

Throughout the study period, the ratios reported by the companies remained at a similar level, outside the optimal intervals for current, quick and cash ratios. The average value of the current ratio for all producer groups and organizations surveyed ranged from 0.95 to 1.15 , changing from one year to another (Table 3 ). On the other hand, the average quick and cash ratios ranged from 0.65 to 0.77 and from 0.05 to 0.08 , respectively. The middle values for current, quick and cash ratios were between $1.03-1.20,0.68-0.74$ and $0.06-0.09$, respectively.

In the producer groups and organizations covered by this study, the assessment of financial liquidity based on the current ratio indicates that, depending on their approval status and legal form, producer groups and limited liability companies may be unable to meet their current liabilities. The average level of the current ratio for producer groups and limited liability companies

Table 3. Liquidity of groups and producer organizations under review in 2012-2015

\begin{tabular}{lcccccc}
\hline \multirow{2}{*}{ Ratios } & \multicolumn{3}{c}{ Years } & & \multicolumn{2}{c}{$\begin{array}{c}\text { Change } \\
\text { 2015-2012 }\end{array}$} \\
\cline { 2 - 7 } & 2012 & 2013 & 2014 & 2015 & in value & $\%$ \\
\hline Geometric mean & & & & & \\
Current ratio (CR) & 0.95 & 0.95 & 1.15 & 1.11 & 0.16 & 16.8 \\
Quick ratio (QR) & 0.68 & 0.65 & 0.77 & 0.67 & -0.01 & -1.5 \\
Cash ratio & 0.05 & 0.07 & 0.08 & 0.05 & 0 & 0 \\
Median & & & & & & -1.0 \\
Current ratio (CR) & 1.04 & 1.05 & 1.20 & 1.03 & -0.01 & -1.4 \\
Quick ratio (QR) & 0.73 & 0.68 & 0.74 & 0.72 & -0.01 & -14.3 \\
Cash ratio & 0.07 & 0.08 & 0.09 & 0.06 & -0.01 & \\
\hline
\end{tabular}

Source: own elaboration. 
ranged from 0.70 to 0.89 and from 0.74 to 0.97 , respectively, which is below the standard values (Table 4). However, other operators remained capable of repaying their current liabilities, as demonstrated by comparing the relevant ratios to optimum values. In 2012-2015, the current ratio ranged from 1.25 to 1.79 for producer organizations; from 1.68 to 2.10 for cooperatives; and from 2.04 to 2.89 for associations (which may indicate excessive liquidity). Similar conclusions were drawn from the analysis of financial liquidity as measured by the quick ratio, ranging from: 0.46 to 0.56 (for producer groups, varying from one year to another); 0.48 to 0.62 (for companies); and 0.73 to 1.33 (for producer organizations). However, the interval reported by cooperatives and associations was 1.18-2.10. The levels of the cash ratio recorded during most of the period under review indicate that the operators used the most liquid assets to repay their liabilities. The ratio ranged from 3\% to $16 \%$, indicating that the operators were struggling to maintain adequate levels of liquidity. As an exception, in 2012, the cooperatives recorded a cash ratio of 0.27 , which is slightly above the optimal level of 0.2 . The analysis also suggests that in the study period, producer groups and companies improved their liquidity situation measured by the current, quick or cash ratios whereas other operators experienced a strong deterioration in that

Table 4. Liquidity of operators surveyed by degree of approval (producer group or organization) and by legal form (company, cooperative or association) in 2012-2015

\begin{tabular}{|c|c|c|c|c|c|c|}
\hline \multirow{2}{*}{ Ratios } & \multicolumn{4}{|c|}{ Years } & \multicolumn{2}{|c|}{ Change 2015-2012 } \\
\hline & 2012 & 2013 & 2014 & 2015 & in value & $\%$ \\
\hline \multicolumn{7}{|l|}{ Producer group } \\
\hline Current ratio (CR) & 0.75 & 0.70 & 0.89 & 0.86 & 0.11 & 14.7 \\
\hline Quick ratio (QR) & 0.49 & 0.46 & 0.48 & 0.56 & 0.07 & 14.3 \\
\hline Cash ratio & 0.03 & 0.03 & 0.06 & 0.05 & 0.02 & 66.7 \\
\hline \multicolumn{7}{|l|}{ Producer organization } \\
\hline Current ratio (CR) & 1.79 & 1.60 & 1.44 & 1.25 & -0.54 & -30.2 \\
\hline Quick ratio (QR) & 1.33 & 1.15 & 0.94 & 0.73 & -0.60 & -45.1 \\
\hline Cash ratio & 0.14 & 0.11 & 0.08 & 0.06 & -0.08 & -57.1 \\
\hline \multicolumn{7}{|l|}{ Company } \\
\hline Current ratio (CR) & 0.74 & 0.80 & 0.97 & 0.97 & 0.23 & 31.1 \\
\hline Quick ratio (QR) & 0.48 & 0.53 & 0.62 & 0.55 & 0.07 & 14.6 \\
\hline Cash ratio & 0.04 & 0.06 & 0.07 & 0.04 & 0 & 0 \\
\hline \multicolumn{7}{|l|}{ Cooperatives } \\
\hline Current ratio (CR) & 2.10 & 1.72 & 1.92 & 1.68 & -0.42 & -20.0 \\
\hline Quick ratio (QR) & 1.80 & 1.32 & 1.52 & 1.18 & -0.62 & -34.4 \\
\hline Cash ratio & 0.27 & 0.10 & 0.16 & 0.12 & -0.15 & -55.6 \\
\hline \multicolumn{7}{|l|}{ Association } \\
\hline Current ratio (CR) & 2.89 & 2.04 & 2.46 & 2.05 & -0.84 & -29.1 \\
\hline Quick ratio (QR) & 2.10 & 1.52 & 1.96 & 1.63 & -0.47 & -22.4 \\
\hline Cash ratio & 0.16 & 0.10 & 0.13 & 0.11 & -0.05 & -31.3 \\
\hline
\end{tabular}

Source: own elaboration. 
Pawlak, J., Kopiński, Ł., Paszko, D., Banach-Albińska, B. (2018). Liquidity as a measure of efficiency of fruit and vegetable producer groups and organizations. J. Agribus. Rural Dev., 2(48), 205-212. http://dx.doi.org/10.17306/J.JARD.2018.00402

Table 5. Liquidity ratios for producer groups and organizations under review in 2012-2015 (\%)

\begin{tabular}{lrrrr}
\hline \multirow{2}{*}{ Ratios } & \multicolumn{4}{c}{ Years } \\
\cline { 2 - 5 } & 2012 & 2013 & 2014 & 2015 \\
\hline Current ratio (CR) & & & & \\
I* & 74.02 & 67.53 & 58.44 & 67.53 \\
II** & 14.29 & 20.78 & 24.68 & 19.48 \\
III*** & 11.69 & 11.69 & 16.88 & 12.99 \\
Quick ratio (QR) & & & & \\
I & 59.74 & 58.44 & 51.95 & 55.85 \\
II & 22.08 & 33.77 & 28.57 & 28.57 \\
III & 18.18 & 7.79 & 19.48 & 15.58 \\
Cash ratio & & & & \\
I & 59.74 & 63.64 & 51.95 & 59.74 \\
II & 33.77 & 29.87 & 38.96 & 31.17 \\
III & 6.49 & 6.49 & 9.09 & 9.09 \\
\hline
\end{tabular}

*Below optimum.

**Optimal.

***Above the recommended optimum.

Source: own elaboration.

area. The value of specific ratios increased by $14.3 \%$ to $66.7 \%$ for producer groups and companies, and declined by $20 \%$ to $57.1 \%$ for other operators.

The average and median values of current, quick and cash ratios resulting from previous research indicated that a large part of the operators surveyed were at risk of losing liquidity. As shown by an in-depth analysis, the size of the group affected by liquidity risk (composed of operators who reported suboptimal levels of current, quick and cash liquidity ratios) varied from year to year, reaching $58-74 \%, 52-60 \%$ and $52-64 \%$ of the population surveyed. Therefore, this group could experience problems in meeting current liabilities in the study period, which presents a serious threat to their efficiency, continued operations and development, thus putting at risk the development of the entire horticultural sector. In addition, based on the current, quick and cash liquidity ratios, the research found that excessive liquidity was reported by ca. $12-17 \%, 8-20 \%$ and $7-9 \%$ of the operators surveyed. This indicates an excessive use of own funds to finance current operations. It can also adversely affect the smooth functioning of the operators and pose a barrier to their development in the next periods.

\section{SUMMARY}

Financial liquidity of producer groups and organizations should be interpreted primarily as an operators' ability to manage its cash flows so as to meet its obligations towards third parties. However, both excessive liquidity (which can restrict the company's ability to grow by reducing its capacity to generate profit) and loss of liquidity (which may lead to insolvency and bankruptcy) are adverse developments. Although a generally accepted liquidity yardstick does not exist, economic operators, including in the agricultural sector, should strive to maintain the essential liquidity ratios within the desired range. The research carried out with the selected population of Polish producer groups and organizations showed that the entrepreneurs struggled to repay their liabilities as they fall due (based on data for average values of current, quick and cash liquidity ratios). For some of the entities surveyed, the risk of losing liquidity was not very high, although a vast majority of ratios under review followed a downward trend. This could be a disadvantageous development in the long run, and may adversely affect the smooth functioning of the entities surveyed. In a sense, this risk also confirms the excessive use of own funds to finance current operations (as it is the case in associations); in the future, it may lead to a decrease in operational efficiency. The results of preliminary analyses justify the need to continue a more detailed research covering a longer period, a broader territory and a larger population. It could provide a basis for more synthetic conclusions on the relationship between liquidity and the development level of groups and organizations of fruit and vegetable producers, and on their impact on the development of horticulture.

\section{REFERENCES}

Bieniasz, A., Gołaś, Z. (2008). Sektorowe zróżnicowanie płynności finansowej przedsiębiorstw w Polsce [Factors Shaping the Level of the Financial Liquidity of Enterprises]. J. Agribus. Rural Dev., 2(8), 13-24 [in Polish].

Boguta, W. (Ed.). (2008). Organizacja i funkcjonowanie grup producentów rolnych [Organization and Functioning of Agricultural Producer Groups]. Warszawa: Kraj. Rada Spółdzielcza [in Polish]. 
Pawlak, J., Kopiński, Ł., Paszko, D., Banach-Albińska, B. (2018). Liquidity as a measure of efficiency of fruit and vegetable producer groups and organizations. J. Agribus. Rural Dev., 2(48), 205-212. http://dx.doi.org/10.17306/J.JARD.2018.00402

Boratyńska, K. (2014). Przyczyny upadłości przedsiębiorstw sektora spożywczego [Reasons of insolvency of food businesses]. In: E. Mączyńska (Ed.), Bankructwa przedsiębiorstw. Wybrane aspekty ekonomiczne i prawne [Business bankruptcy. Selected economic and legal aspects] (pp. 127-136). Warszawa: Wyd. SGH [in Polish].

Camanzi, L., Malorgio, G., García Azcárate, T. (2009). The role of Producer Organizations in supply concentration and marketing: a comparison between European Countries in the fruit and vegetables sector. Retrieved June 30th 2017 from: http://ageconsearch.umn.edu

Chlebicka, A. (2011). Czynniki wpływające na sukces grup producentów rolnych [Factors Affecting Success of Agricultural Producers Groups]. J. Agribus. Rural Dev., 4(22), 31-39 [in Polish].

Cicirko, T. (2010). Podstawy zarządzania płynnością finansową przedsiębiorstwa [Basics Liquidity Management Companies]. Warszawa: SGH [in Polish].

Czernyszewicz, E., Pawlak, J. (2012). Integracja w ogrodnictwie-uwarunkowania, korzyści i bariery [Integration in Horticulture - Conditions, Benefits and Barriers]. In: E. Skrzypek (Ed.), Zintegrowany system zarządzania w organizacjach [Integrated management system in organizations] (pp. 313-332). Lublin: UMCS [in Polish].

Filipiak, T. (2013). Grupy producentów owoców i warzyw w Polsce [Producers Groups of Fruit and Vegetables in Poland]. Rocz. Nauk. SERiA, XV (6), 69-74 [in Polish].

Florek, J., Czerwińska-Kayzer, D. (2012). Kształtowanie płynności finansowej i wypłacalności w przedsiębiorstwach produkujących pasze [Evaluation of Liquidity and Gearing in Animal Feed Producing Enterprises]. ZN SGGW, Ser. Ekon. i Org. Gosp. Żywn. 97, 81-91 [in Polish].

Gabrusewicz, W. (2005). Podstawy analizy finansowej [Basics of Financial Analysis]. Warszawa: PWE [in Polish].

Kwiecień, A. (2015). Zarządzanie płynnością jako sposób na poprawę efektywności w zarządzaniu finansami [Liquidity management as a way to improve the efficiency in financial management]. ZN Uniw. Szczec. 854 Fin. Rynki Fin. Ubezp., 73, 39-46 [in Polish].

Makać, W., Urbanek-Krzysztofiak, D. (2004). Metody opisu statystycznego [Methods of Statistical Description]. Gdańsk: Wyd. Uniwersytetu Gdańskiego [in Polish].
Mańko, S., Sobczyński, T., Sass, R. (2008). Zmiany poziomu zrównoważenia płynności finansowej w gospodarstwach rolniczych UE w latach 1989-2005 [Changes in Balancing of Financial Liquidity in the European Union's Agricultural Farms in the Years 1989-2005]. ZN SGGW Ekon. Org. Gosp. Żywn. 64, 5-22 [in Polish].

Nowak, A., Gąsior, R. (2017). Integracja pozioma producentów rolnych - możliwości i bariery [Horizontal Integration of Agricultural Producers - Possibilities and Barriers]. Ann. UMCS Lublin, LI, 1, H, 63-72 [in Polish].

Rogowski, W. (2015). Przyczyny upadłości polskich przedsiębiorstw - aspekt teoretyczny [Reasons for Bankruptcies of Polish Companies. A Theoretical Aspect]. Stud. Prac. Kol. Zarz. Fin. Zesz. Nauk., 143, 119-154 [in Polish].

Sierpińska, M., Wędzki, D. (2005). Zarządzanie płynnością finansową w przedsiębiorstwie [Financial Liquidity Management in an Enterprise]. Warszawa: Wyd. Nauk. PWN [in Polish].

Sobczak, W., Jabłońska, L., Dziedzic, A. (2013). Korzyści członkostwa $\mathrm{w}$ grupie producentów owoców i warzyw w opinii ogrodników [Benefits of Membership in the Group of Fruit and Vegetable Producers in Their Opinion]. Rocz. Nauk. SERiA, XV(3), 306-311 [in Polish].

Strategia Krajowa dla Zrównoważonych Programów Operacyjnych Organizacji Producentów Owoców i Warzyw oraz Zrzeszeń Organizacji Producentów Owoców i Warzyw w Polsce na lata 2010-2017. [National Strategy for Sustainable Operational Programs of the Fruit and Vegetable Producers Organization and the Association of Fruit and Vegetable Producers Organizations in Poland for 2010-2017] (2016). Warszawa: MRiRW [in Polish].

Wasilewski, M. (2005). Strategia płynności finansowej $\mathrm{w}$ przedsiębiorstwach agrobiznesu [Financial Liquidity Strategy in Agribusiness Enterprises]. Rocz. Nauk. SERiA, VII (1), 269-277 [in Polish].

Woźniak, M. (Ed.). (2002). Statystyka ogólna [General Statistics]. Kraków: Wyd. AE w Krakowie [in Polish].

Zmarlicki, K., Brzozowski, P., Karmańska, M. (2013). Analiza SWOT warunków i czynników determinujących powstawanie grup producenckich. [SWOT Analysis of Conditions and Factors Determining the Formation of Producer Groups]. Skierniewice: Instytut Ogrodnictwa [in Polish]. 